\title{
Defining a Clinical Prediction Rule to Diagnose Bacterial Gastroenteritis Requiring Empirical Antibiotics in an Emergency Department Setting: a Retrosepctive Review
}

\author{
Michael De Dios \\ $\mathrm{Ng}$ Teng Fong General Hospital \\ Shanaz Sajeed ( $\square$ shanazsajeed@gmail.com ) \\ $\mathrm{Ng}$ Teng Fong General Hospital \\ Dan Ong Wei Jun \\ $\mathrm{Ng}$ Teng Fong General Hospital \\ Amila Clarence Punyadasa \\ $\mathrm{Ng}$ Teng Fong General Hospital
}

Original Research

Keywords: Gastroenteritis, prediction-rule, bacterial, scoring

Posted Date: April 1st, 2021

DOl: https://doi.org/10.21203/rs.3.rs-378454/v1

License: (c) (1) This work is licensed under a Creative Commons Attribution 4.0 International License.

Read Full License 


\section{Abstract}

\section{BACKGROUND}

Gastroenteritis (GE) is a nonspecific term for various pathologic states of the gastrointestinal tract. Infectious agents usually cause acute gastroenteritis. At present, there are no robust decision-making rules that predict bacterial GE and hence dictate when to start antibiotics in patients presenting with acute GE to the ED. We aim to define a clinical prediction rule to diagnose bacterial gastroenteritis requiring empirical antibiotics in an emergency department setting.

\section{METHODS}

A 2-year retrospective case review was performed on all cases from July 2015 to June 2017 that presented acutely with infectious GE symptoms to the Emergency Department and then had stool cultures performed. The clinical parameters analysed included patient co-morbid conditions, physical examination findings, historical markers, point of care tests and other laboratory work. We then used multivariate logistic regression analysis on each group (Bacterial culture-positive GE and Bacterial culture-negative GE) to elucidate clinical criteria with the highest yield for predicting BGE.

\section{RESULTS}

756 patients with a mean age of 52 years, $52 \%$ of whom were female, and $48 \%$ male, were recruited into the study. Based on the data from these patients, we suggest using a scoring system to delineate the need for empirical antibiotics in patients with suspected bacterial GE based on six clinical and laboratory variables. A score 0-3 points on the suggests low risk (5.8\%) of bacterial GE. A score of 4-5 points confers an intermediate risk of $28.5 \%$ and a score of $6-8$ points confers a high risk of $66.7 \%$. A cut-off of $\geq 5$ points may be used to predict culture positive BGE with a $75 \%$ sensitivity and $75 \%$ specificity. The AUROC for the scoring system (range $0-8$ ) is $0.812 \pm 0.016(95 \% \mathrm{Cl}$ : $0.780-0.843)$ p-value $<0.001$.

\section{CONCLUSION}

While this is a pilot study which will require further validation with a larger sample size, our proposed decision-making rule will potentially serve to improve diagnosis of BGE, reduce unnecessary prescribing of antibiotics which will in turn reduce antibiotic associated adverse events and save costs worldwide.

\section{Introduction}

Gastroenteritis (GE) represents a nebulous term for a variety of pathologic states of the gastrointestinal tract. It is however commonly used to define an acute infection of the gastrointestinal tract that manifests principally as diarrhea. A universal definition of diarrhea does not exist. Most definitions center upon the frequency, consistency, and water content of stools [1]. It has also been defined as stools that take the shape of their container. Although the primary manifestation is diarrhea, GE may present as a quadrad of signs and symptoms that include nausea and/or vomiting, fever and abdominal pain. [2] 
Infectious agents usually cause acute gastroenteritis. These agents cause diarrhea by adherence, mucosal invasion, enterotoxin production, and/or cytotoxin production. Dehydration, fluid loss and electrolyte abnormalities result as a consequence of increased fluid secretion and/or decreased absorption.[2]

Acute gastroenteritis outbreaks are a public health concern throughout the world due to their associated morbidity. Aetiological agents can be viral, bacterial or protozoal. The bacterial agents can be either enteropathogenic, toxigenic or both. While the main goals in management in the emergency department (ED) are symptomatic treatment and hydration, some patients are started on antibiotics for presumptive bacterial gastroenteritis (BGE) whilst only a minority actually receive stool cultures to definitively ascertain the causative agent of their GE. The American College of Gastroenterology (ACG) guidelines recommend stool cultures in presence of severe diarrhoea (defined as greater than 6 times in a 24-hour period), temperature $>38.5^{\circ} \mathrm{C}$ (taken orally), passage of bloody stools, persistent diarrhea which was defined as greater than 3 days duration [3]. However, there are no robust decision-making rules that predict bacterial GE which dictate when to start antibiotics in patients presenting with acute GE to the ED, although a few have been proposed for example by Cadwgan et al (2000) [4]. We aim to derive a clinical prediction rule based on both historical and laboratory markers to help predict BGE.

\section{Methodology}

Intuitively, BGE could be defined if any of the following criteria were satisfied:

1) Moderate to severe functional disease with temperature of $>38.3^{\circ} \mathrm{C}\left(>101^{\circ} \mathrm{F}\right)$ and $>3$ days duration of symptoms

Disease severity being defined as

Severe - total disability due to diarrhea;

Moderate - able to function but with forced change in activities due to illness.

2) Traveller's diarrhoea

3) Dysentery defined as passage of blood (in the absence of hemorrhoids) with watery stools

4) Patients presenting with watery diarrhea and having positive stool cultures for bacteria [1].

We collated all patients presenting to the ED of an acute care hospital in Singapore with symptoms consistent with gastroenteritis who then had stool cultures performed and subdivided them into 2 groups:

A. Those with bacterial culture-positive GE (BGE) and

B. Those with bacterial culture-negative GE (NBGE). 
We appreciate that the diagnostic yield of stool cultures is low, with Slutsker et al[5] finding only $5.6 \%$ of cultures producing bacterial isolates and other studies demonstrating yields as low as $1.5 \%[6]$. Hence, instead of subdividing our patients into bacterial gastroenteritis and non-bacterial gastroenteritis, we used stool cultures to define bacterial culture-positive gastroenteritis (patients with GE with positive stool cultures) and those with bacterial culture-negative gastroenteritis (patients with GE with stool cultures negative for bacteria).

We then performed a multivariate logistic regression analysis to derive a clinical decision-making rule that will aid physicians in ambulatory settings, such as ED physicians, in regard to diagnosing BGE and thus aid antibiotic prescribing practices.

A 2 year retrospective case review was performed on all patients from July 2015 to June 2017 who presented acutely with infectious GE symptoms to the ED of an acute care hospital in Singapore and then had stool cultures performed. These cases were collated and the presenting history (with cardinal presenting symptoms that include vomiting, diarrhea, abdominal pain and fever) and examination was reviewed by an independent ED specialist/gastroenterologist to ensure congruity with the final appended diagnosis of Gastroenteritis. If incongruent with the initial diagnosis of GE, the patient was excluded from our study.

The data was gathered from the review of electronic medical records (EPIC electronic case database) of the selected patients based on a specific proforma and entered into an Excel spreadsheet. The clinical parameters analyzed included patient co-morbid conditions, physical examination findings, historical markers, point of care tests and other laboratory work. We then used multivariate logistic regression analysis on each group (Bacterial culture-positive GE and Bacterial culture-negative GE) to elucidate clinical criteria with the highest yield for predicting BGE. The ultimate objective was to incorporate these high yield criteria into a clinical prediction score or rule which will be able to aid physicians in ambulatory settings, such as ED physicians, in regard to diagnosing BGE and thus aid antibiotic prescribing practices.

Exclusion criteria were previous recent antibiotic use, urinary tract infection (UTI) symptoms, prolonged recent inpatient stay, chronic episodes of diarrhea such as seen in irritable bowel syndrome, gastrointestinal neoplasias or bleeding and diarrhea related to inflammatory bowel disease such as Crohn's or ulcerative colitis and the incongruence of clinical notes with diagnosis of GE. (See Fig. 1). Ethics approval from the National Health Group Domain Specific Review Board was obtained for the collection and analysis of data.

\section{Results}

Seven hundred fifty-six patients with a mean age of 52 years, $52 \%$ of whom were female, and $48 \%$ male, were recruited into the study. A vast majority (99.9\%) reported diarrhea as the main symptom, with $77.5 \%$ reporting watery type of stools. The subjects had a median number of 7 episodes of diarrhea per day. Other main symptoms were abdominal pain reported by $67.2 \%$, while $64.1 \%$ and $61 \%$ had vomiting and nausea respectively. A majority of the subjects were BGE negative on stool culture $(n=611,80.8 \%)$. 
The subjects had a median temperature of $37.2^{\circ} \mathrm{C}$ with about half $(49.1 \%)$ reporting to have had fever subjectively prior to coming to the ED. Median C-reactive protein was 51.9 with a range of 12.9-140.5 $\mathrm{mmol} / \mathrm{L}$. Serum sodium median was $136 \mathrm{mmol} / \mathrm{L}$ (range of $133 \mathrm{mmol} / \mathrm{L}-138 \mathrm{mmol} / \mathrm{L}$ ). Neutrophil count median was $8.7\left(\times 10^{9} / \mathrm{L} / \mathrm{L}\right)$ with a range of $5.3-12.39\left(\times 10^{9} / \mathrm{L} / \mathrm{L}\right)$.

\section{STATISTICAL ANALYSIS}

Categorical variables were reported as proportions and were compared using the Chi-square and Fisher's Exact test, if the expected count was less than 5 . Normally distributed continuous variables were reported as means (standard deviation, SD) and were compared using the Student T test and ANOVA. Nonparametric data were reported as medians (interquartile range, IQR) and compared using the MannWhitney $U$ test. To determine factors independently associated with positive BGE, variables with $p<0.2$ on univariate analysis were entered into a multivariable logistic regression model. Hosmer Lemeshow test was performed for model calibration to assess agreement between predicted and observed probabilities. All tests were two sided and statistical significance was set at $\mathrm{P}<0.05$. All statistical analysis was conducted using SPSS statistical package (version 23.0 SPSS Inc., Chicago, Illinois, USA). Tables 1 to 3 show the characteristics and laboratory results of included patients. 
Table 1

Baseline Demographics, Characteristics, Co-morbidities and Risk factors

\begin{tabular}{|c|c|c|c|c|}
\hline & $\begin{array}{l}\text { All Patients } \\
(n=756)\end{array}$ & $\begin{array}{l}\text { BGE } \\
\text { Negative } \\
(n=611)\end{array}$ & $\begin{array}{l}\text { BGE Positive } \\
(n=145)\end{array}$ & p-value \\
\hline Age (Years) [mean \pm SD] & $\begin{array}{l}52.11 \pm \\
20.06\end{array}$ & $\begin{array}{l}52.48 \pm \\
19.81\end{array}$ & $\begin{array}{l}50.58 \pm \\
21.09\end{array}$ & 0.306 \\
\hline Female [n (\%)] & $396(52.5 \%)$ & $323(53.0 \%)$ & $73(50.3 \%)$ & 0.572 \\
\hline Diarrhoea [n (\%)] & $749(99.9 \%)$ & $\begin{array}{l}605 \\
(100.0 \%)\end{array}$ & $144(99.3 \%)$ & 0.153 \\
\hline Blood in Stool [n (\%)] & $21(2.8 \%)$ & $20(3.3 \%)$ & $1(0.7 \%)$ & 0.103 \\
\hline Mucous with Stool [n (\%)] & $26(3.4 \%)$ & $22(3.6 \%)$ & $4(2.8 \%)$ & 0.801 \\
\hline Nausea [n (\%)] & $460(61.0 \%)$ & $365(59.9 \%)$ & $95(65.5 \%)$ & 0.215 \\
\hline Vomiting [n (\%)] & $484(64.1 \%)$ & $398(65.2 \%)$ & $86(59.3 \%)$ & 0.180 \\
\hline Abdominal Pain [n (\%)] & $501(67.2 \%)$ & $402(66.7 \%)$ & $99(69.7 \%)$ & 0.486 \\
\hline Fever [n (\%)] & $368(49.1 \%)$ & $268(44.3 \%)$ & $100(69.0 \%)$ & $\hat{0}_{0.001 *}$ \\
\hline Myalgia [n (\%)] & $42(7.4 \%)$ & $34(7.2 \%)$ & $8(8.1 \%)$ & 0.765 \\
\hline Travel History [n (\%)] & $112(15.6 \%)$ & $93(16.0 \%)$ & $19(13.9 \%)$ & 0.540 \\
\hline Sick Contacts with Gastroenteritis [n (\%)] & $105(14.5 \%)$ & $83(14.2 \%)$ & $22(15.7 \%)$ & 0.639 \\
\hline $\begin{array}{l}\text { Recent Gatherings with Communal } \\
\text { Eating } \\
\text { [n (\%)] }\end{array}$ & $58(8.1 \%)$ & $43(7.4 \%)$ & $15(10.8 \%)$ & 0.187 \\
\hline Febrile [n (\%)] & $291(38.8 \%)$ & $220(36.4 \%)$ & $71(49.0 \%)$ & $0.005^{\star}$ \\
\hline $\begin{array}{l}\text { Presence for Signs of Dehydration [n } \\
(\%)]\end{array}$ & $385(54.5 \%)$ & $310(54.0 \%)$ & 75 (56.8\%) & 0.559 \\
\hline Abdominal Tenderness [n (\%)] & $240(31.8 \%)$ & $190(31.1 \%)$ & $50(34.5 \%)$ & 0.438 \\
\hline $\begin{array}{l}\text { Number of Episode (per day) [median } \\
(\text { IQR)] }\end{array}$ & $\begin{array}{l}7.0(4.0- \\
10.0)\end{array}$ & $\begin{array}{l}7.0(4.0- \\
10.0)\end{array}$ & $\begin{array}{l}8.0(5.0- \\
10.0)\end{array}$ & 0.209 \\
\hline Duration (days) [median (IQR)] & $2.0(1.0-3.0)$ & $2.0(1.0-3.0)$ & $2.0(1.3-3.0)$ & 0.136 \\
\hline $\begin{array}{l}\text { Number of Vomiting Episodes } \\
\text { [median (IQR)] }\end{array}$ & $\begin{array}{l}5.0(3.0- \\
10.0)\end{array}$ & $\begin{array}{l}5.0(3.0- \\
10.0)\end{array}$ & $\begin{array}{l}5.0(3.0- \\
10.0)\end{array}$ & 0.753 \\
\hline${ }^{*}$ p-value $<0.05$ & & & & \\
\hline
\end{tabular}


Page $7 / 15$ 
Table 2

Vital Signs and laboratory parameters

\begin{tabular}{|c|c|c|c|c|}
\hline & $\begin{array}{l}\text { All Patients } \\
(n=756)\end{array}$ & $\begin{array}{l}\text { BGE Negative } \\
(n=611)\end{array}$ & $\begin{array}{l}\text { BGE Positive } \\
(n=145)\end{array}$ & $\begin{array}{l}\text { p- } \\
\text { value }\end{array}$ \\
\hline Heart Rate (BPM) [mean \pm SD] & $90.03 \pm 19.52$ & $90.03 \pm 19.84$ & $90.03 \pm 18.21$ & 0.999 \\
\hline $\begin{array}{l}\text { Systolic Blood Pressure }(\mathrm{mmHg}) \\
\text { [mean } \pm \text { SD] }\end{array}$ & $124.08 \pm 22.63$ & $124.27 \pm 22.67$ & $123.28 \pm 22.55$ & 0.635 \\
\hline $\begin{array}{l}\text { Diastolic Blood Pressure }(\mathrm{mmHg}) \\
\text { [mean } \pm \text { SD] }\end{array}$ & $72.48 \pm 13.70$ & $72.33 \pm 13.49$ & $73.11 \pm 14.59$ & 0.537 \\
\hline $\begin{array}{l}\text { Mean Arterial Pressure }(\mathrm{mmHg}) \\
\text { [mean } \pm \text { SD] }\end{array}$ & $89.68 \pm 14.62$ & $89.64 \pm 14.49$ & $89.83 \pm 15.22$ & 0.889 \\
\hline Haemotocrit (\%) [mean \pm SD] & $40.78 \pm 6.88$ & $40.50 \pm 6.84$ & $41.96 \pm 6.97$ & $0.023 *$ \\
\hline Haemoglobin $(\mathrm{g} / \mathrm{L})[$ mean $\pm \mathrm{SD}]$ & $13.66 \pm 3.01$ & $13.57 \pm 2.96$ & $14.04 \pm 3.19$ & 0.092 \\
\hline Temperature $\left({ }^{\circ} \mathrm{C}\right)$ [median (IQR)] & $\begin{array}{l}37.2(36.6- \\
38.1)\end{array}$ & $\begin{array}{l}37.1(36.6- \\
38.0)\end{array}$ & $\begin{array}{l}37.3(36.7- \\
38.4)\end{array}$ & $0.013^{*}$ \\
\hline $\begin{array}{l}\text { White Blood Cells Count (x109/L) } \\
\text { [median (IQR)] }\end{array}$ & $\begin{array}{l}10.9(7.4- \\
14.4)\end{array}$ & $11.2(7.8-14.6)$ & $9.3(6.4-14.0)$ & $0.003^{*}$ \\
\hline $\begin{array}{l}\text { Neutrophil Count }\left(x 10^{9} / \mathrm{L}\right) \text { [median } \\
(\mathrm{IQR}) \text { ] }\end{array}$ & $8.7(5.3-12.3)$ & $9.1(5.5-12.4)$ & $7.4(4.7-12.1)$ & $0.017 *$ \\
\hline $\begin{array}{l}\text { C-Reactive Protein (mg/L) [median } \\
\text { (IQR)] }\end{array}$ & $\begin{array}{l}51.9(12.9- \\
140.5)\end{array}$ & $\begin{array}{l}44.4(10.7- \\
132.4)\end{array}$ & $\begin{array}{l}95.1(27.3- \\
149.4)\end{array}$ & $0.008^{*}$ \\
\hline $\begin{array}{l}\text { Serum Urea (mmol/L) } \\
\text { [median (IQR)] }\end{array}$ & $5.6(3.9-8.6)$ & $5.5(3.9-8.5)$ & $5.8(3.8-10.1)$ & 0.760 \\
\hline $\begin{array}{l}\text { Serum Creatinine }(\mu \mathrm{mol} / \mathrm{L}) \text { [median } \\
(\mathrm{IQR})]\end{array}$ & $\begin{array}{l}84.0(63.0- \\
127.0)\end{array}$ & $\begin{array}{l}82.0(63.0- \\
122.5)\end{array}$ & $\begin{array}{l}94(65.0- \\
149.0)\end{array}$ & 0.085 \\
\hline $\begin{array}{l}\text { Serum Sodium (mmol/L) } \\
\text { [median (IQR)] }\end{array}$ & $\begin{array}{l}136.0(133.0- \\
138.0)\end{array}$ & $\begin{array}{l}136.0(134.0- \\
139.0)\end{array}$ & $\begin{array}{l}135.0(131.0- \\
138.0)\end{array}$ & $0.001 *$ \\
\hline $\begin{array}{l}\text { Serum Potassium (mEq/L) [median } \\
\text { (IQR)] }\end{array}$ & $3.9(3.5-4.2)$ & $3.9(3.5-4.2)$ & $3.8(3.5-4.2)$ & 0.157 \\
\hline $\begin{array}{l}\text { Serum Bicarbonate (mEq/L) } \\
\text { [median (IQR)] }\end{array}$ & $\begin{array}{l}20.0(18.0- \\
22.0)\end{array}$ & $\begin{array}{l}20.0(18.0- \\
22.0)\end{array}$ & $\begin{array}{l}19.0(17.5- \\
22.0)\end{array}$ & 0.278 \\
\hline $\begin{array}{l}\text { Serum Lactate (mmol/L) } \\
\text { [median (IQR)] }\end{array}$ & $1.9(1.4-2.9)$ & $1.9(1.4-2.9)$ & $1.7(1.2-2.7)$ & 0.257 \\
\hline
\end{tabular}

IQR - Interquartile range ${ }^{*} \mathrm{p}$-value $<0.05$ 


\begin{tabular}{|lllll|}
\hline & $\begin{array}{l}\text { All Patients } \\
(\mathbf{n = 7 5 6 )}\end{array}$ & $\begin{array}{l}\text { BGE Negative } \\
\mathbf{( n = 6 1 1 )}\end{array}$ & $\begin{array}{l}\text { BGE Positive } \\
\mathbf{( n = 1 4 5 )}\end{array}$ & $\begin{array}{l}\text { p- } \\
\text { value }\end{array}$ \\
\hline Anion Gap (mEq/L) & $15.7(14.1-$ & $\begin{array}{l}15.7(14.0- \\
18.0)\end{array}$ & $\begin{array}{l}15.9(14.5- \\
18.2)\end{array}$ & 0.294 \\
[median (IQR)] & $18.0)$ & & & \\
\hline $\begin{array}{l}\text { Serum Chloride (mmol/L) [median } \\
\text { (IQR)] }\end{array}$ & $\begin{array}{l}104.0(101.0- \\
107.0)\end{array}$ & $\begin{array}{l}104.0(101.5- \\
107.0)\end{array}$ & $\begin{array}{l}103.0(99.0- \\
106.5)\end{array}$ & $0.005^{\star}$ \\
\hline IQR - Interquartile range *p-value< 0.05 & & & \\
\hline
\end{tabular}

Table 3

Diagnostics Findings

\begin{tabular}{|lllll|}
\hline & $\begin{array}{l}\text { All } \\
\text { Patients } \\
(\mathbf{n = 7 5 6 )}\end{array}$ & $\begin{array}{l}\text { BGE } \\
\text { Negative } \\
(\mathbf{n = 6 1 1})\end{array}$ & $\begin{array}{l}\text { BGE } \\
\text { Positive } \\
(\mathbf{n}=145)\end{array}$ & p-value \\
\hline Nature of Stool being watery [n (\%)] & $\begin{array}{l}586 \\
(77.5 \%)\end{array}$ & $458(75.0 \%)$ & $128(88.3 \%)$ & $0.001^{*}$ \\
\hline $\begin{array}{l}\text { Digital Rectal Examination Blood in Stool [n } \\
\text { (\%)] }\end{array}$ & $\begin{array}{l}446 \\
(59.0 \%)\end{array}$ & $358(58.6 \%)$ & $88(60.7 \%)$ & 0.644 \\
\hline Positive Blood Culture Results [n (\%)] & $\begin{array}{l}475 \\
(62.8 \%)\end{array}$ & $387(63.3 \%)$ & $88(60.7 \%)$ & 0.553 \\
\hline Positive Stool Culture Results [n (\%)] & $\begin{array}{l}147 \\
(19.4 \%)\end{array}$ & $2(0.3 \%)$ & 145 & $<$ \\
\hline Positive Findings in AXR or CT report [n(\%)] & $\begin{array}{l}652 \\
(86.2 \%)\end{array}$ & $521(85.3 \%)$ & $131(90.3 \%)$ & 0.111 \\
\hline *p-value < 0.05 & & & & \\
\hline
\end{tabular}

A non-parametric test was performed for laboratory result and proportional chi-square test for the categorical variables with $p$-value $<0.1$ deemed to be significant.

The following variables are significant at $\mathrm{P}<0.1$ :

- Serum Sodium

- Serum Chloride

- C-Reactive Protein

- Haemoglobin

- Haematocrit

- Neutrophil Count 
- White Blood Cell Count

- Objective fever

- Subjective feeling of being febrile

- Watery Stool

The sensitivity of at least 0.7 was used to determine the cut-off of each continuous variable. However, due to the small sample size of BGE positive from stool result $(n=61)$, six were identified as the variables of interest in the study.

The six variables are as follow with their cut-off values:

- Serum Sodium (<135 mmol/L) -1 point

- C-Reactive Protein

- $10 \mathrm{mg} / \mathrm{L}$ to $16.5 \mathrm{mg} / \mathrm{L}-1$ point

- $16.6 \mathrm{mg} / \mathrm{L}-24.9 \mathrm{mg} / \mathrm{L}-2$ points

- $>25 \mathrm{mg} / \mathrm{L}-3$ points

- Neutrophil count $\left(>8 \times 10^{9} / \mathrm{L}\right)-1$ point

- Objective fever (Yes) - 1 point

- Subjective feeling of being febrile (Yes) - 1 point

- Watery Stool (Yes) - 1 point

\section{Discussion}

The pathogenesis of GE is usually multi-factorial but often occurs when microbial virulence overwhelms normal host defenses. The acidity of the stomach and colon is an effective antimicrobial defense. When this normal acidity is disrupted, for example, in achlohyric states (ie, caused by antacids, histamine-2 blockers, gastric surgery, decreased colonic anaerobic flora), this defense is significantly weakened. The host's capacity to mount an effective defense may be compromised by a large inoculum of offending viruses, bacteria or protozoa. An alteration of normal bowel flora can create a biologic void that is filled by pathogens. This occurs most commonly after antibiotic administration. Hypomotility states may result in colonization by pathogens, especially in the proximal small bowel, where motility is the major mechanism in the removal of organisms. Hypomotility may be induced by anti-peristaltic agents or anomalous anatomy and is common in patient with co-morbidities such as diabetes mellitus or scleroderma. In addition, immunocompromised hosts are more susceptible to infection by a wide variety of pathogens. [2]

Diarrhea is one of the most common reasons patients seek medical care. In the developed world, it is one of the most common reasons for time off work, while in the developing world, it is a leading cause of mortality. According to a publication by Wilkoswo et al, an estimated 179 million cases of acute gastroenteritis occur every year in the United States. Of these patients, the vast majority $(80-85 \%)$ do not 
seek medical attention, and only a minority (1-2\%) require hospital admission[7]. If allowed to reach epidemic proportions, diarrheal illnesses can quickly overwhelm health care systems.

The burden of disease is often under-reported in adults. Each year, gastroenteritis in adults accounts for 8 million doctor visits and 250,000 hospitalizations and often occur in the setting of localized outbreaks. Furthermore, traveler's diarrhea affects $20-50 \%$ of people traveling from industrialized to developing countries $[8,9,10,11]$

Appropriate management of GE requires extensive history and assessment, an accurate diagnosis and then appropriate, general supportive treatment that is often aetiology specific. Patient history and examination alone have been found to be notoriously poor at differentiating BGE from NBGE [12]. However, epidemiological studies have noted that the prevalence of BGE is approximately one third that of NBGE. $[1,8]$

With the data in Table 4, we suggest using a scoring system to delineate the need for empirical antibiotics in patients with suspected bacterial GE.

Table 4

Recommended scoring system for bacterial gastroenteritis

\begin{tabular}{|lll|}
\hline Variables & Range & Points \\
\hline Serum Sodium & $<135 \mathrm{mmol} / \mathrm{L}$ & 1 \\
\hline C-Reactive Protein & $10 \mathrm{mg} / \mathrm{L}-16.5 \mathrm{mg} / \mathrm{L}$ & 1 \\
\cline { 2 - 3 } & $16.6 \mathrm{mg} / \mathrm{L}-24.9 \mathrm{mg} / \mathrm{L}$ & 2 \\
\cline { 2 - 3 } & $>25 \mathrm{mg} / \mathrm{L}$ & 3 \\
\hline Neutrophil & $>8.0 \times 10^{9} / \mathrm{L}$ & 1 \\
\hline Temperature & $>37.5^{\circ} \mathrm{C}$ & 1 \\
\hline Febrile & Yes & 1 \\
\hline Watery Stool & Yes & 1 \\
\hline Total & $\geq 5$ points determine the high possibility of positive BGE & 8 \\
\hline
\end{tabular}

Based on the rate of BGE associated with each score as shown in Fig. 2., a score $0-3$ points suggests low risk (5.8\%) of bacterial GE. A score of 4-5 points confers an intermediate risk of $28.5 \%$ and a score of 6-8 points confers a high risk of $66.7 \%$. A cut-off of $>5$ points may be used to predict culture positive BGE with a $75 \%$ sensitivity and $75 \%$ specificity. The AUROC for the scoring system (range $0-8$ ) is $0.812+$ 0.016 (95\% Cl: 0.780-0.843) p-value $<0.001$. 
The most common antibiotic prescribed for BGE in adults is a 3-day course of Ciprofloxacin which costs approximately S\$ 6 per course. The financial magnitude of the problem is thus potentially astounding. Assuming that $20 \%$ of BGE presenting to ambulatory settings received antibiotics world-wide based on physician judgement but that a decision making rule would allow for a more accurate identification of BGE thus halving antibiotic prescriptions to $10 \%$ of all BGE patients this would result in savings of $\$ 1.2$ million worldwide (assuming above mentioned incidence of 8 million doctor visits per year). Economics aside, another important benefit would be to save these select patients (NBGE) from the adverse effects that are the inevitable concomitance of needless antibiotic administration.

While this is a pilot study which will require further validation with a larger sample size, our proposed decision-making rule will potentially serve to improve diagnosis of BGE, reduce unnecessary prescribing of antibiotics which will in turn reduce antibiotic associated adverse events and save costs worldwide.

\section{Abbreviations}

$\mathrm{GE}=$ Gastroenteritis

$\mathrm{ED}=$ Emergency Department

$\mathrm{BGE}=$ Bacterial Gastroenteritis

NBGE $=$ Non Bacterial Gastroenteritis

$A C G=$ American College of Gastroenteritis

UTI = Urinary Tract Infection

AUROC $=$ Area under the Receiver Operating Characteristic Curve

$\mathrm{SD}=$ Standard Deviation

$\mathrm{IQR}=$ Inter-quartile Range

\section{Declarations}

\section{Ethics approval and Consent to Participate}

Ethical approval was obtained by the Domain Specific Review Board of the National Health Group for the use of patient's data.

\section{Consent for publication}

Not applicable. 


\section{Availability of data and materials}

The datasets used and/or analyzed during the current study are available from the corresponding author on reasonable request.

\section{Competing interests}

The authors declare that they have no competing interests

\section{Funding}

Not applicable

\section{Authors contributions}

ACP is the project mentor who wrote the protocol and obtained ethics approval as well as collected data. SMS, MPD assisted with the data analysis and data collection sheet. OWJD did the statistical analysis. MPD and SMS wrote the manuscript and this were read and approved by all authors.

\section{Acknowledgements}

Not applicable

\section{References}

1. Riddle MS, DuPont HL, Connor BA. ACG Clinical Guideline: Diagnosis, Treatment, and Prevention of Acute Diarrheal Infections in Adults. Am J Gastroenterol. 2016 May;111(5):602-22. doi:

10.1038/ajg.2016.126. Epub 2016 Apr 12. PMID: 27068718.

2. Arthur D. Emergent Treatment of Gastroenteritis. Medscape. 2020 Dec. emedicine.medscape.com/article/775277-overview.

3. Park SI, Giannella RA. Approach to the adult patient with acute diarrhea. Gastroenterol Clin North Am. 1993 Sep;22(3):483-97. PMID: 8406726.

4. Cadwgan AM, Watson WA, Laing RB, MacKenzie AR, Smith CC, Douglas JG. Presenting clinical features and C-reactive protein in the prediction of a positive stool culture in patients with diarrhoea. J Infect. 2000 Sep;41(2):159-61. doi: 10.1053/jinf.2000.0717. PMID: 11023761.

5. Slutsker L, Ries AA, Greene KD, Wells JG, Hutwagner L, Griffin PM. Escherichia coli 0157:H7 diarrhea in the United States: clinical and epidemiologic features. Ann Intern Med. 1997 Apr 1;126(7):505-13. doi: 10.7326/0003-4819-126-7-199704010-00002. PMID: 9092315. 
6. Guerrant RL, Van Gilder T, Steiner TS, Thielman NM, Slutsker L, Tauxe RV, et al; Infectious Diseases Society of America. Practice guidelines for the management of infectious diarrhea. Clin Infect Dis. 2001 Feb 1;32(3):331-51. doi: 10.1086/318514. Epub 2001 Jan 30. PMID: 11170940.

7. Wikswo ME, Hall AJ. Outbreaks of acute gastroenteritis transmitted by person-to-person contactUnited States, 2009-2010. MMWR Surveill Summ. 2012 Dec 14. 61(9):1-12.

8. Steffen R. Epidemiology of Traveler's Diarrhea, Clinical Infectious Diseases, Volume 41, Issue Supplement_8, December 2005, Pages S536-S540, https://doi.org/10.1086/432948

9. Steffen R, Collard F, Tornieporth N, Campbell-Forrester S, Ashley D, Thompson S, et al. Epidemiology, etiology, and impact of traveler's diarrhea in Jamaica. JAMA. 1999 Mar 3;281(9):811-7. doi: 10.1001/jama.281.9.811. PMID: 10071002.

10. Streit JM, Jones RN, Toleman MA, Stratchounski LS, Fritsche TR. Prevalence and antimicrobial susceptibility patterns among gastroenteritis-causing pathogens recovered in Europe and Latin America and Salmonella isolates recovered from bloodstream infections in North America and Latin America: report from the SENTRY Antimicrobial Surveillance Program (2003). Int J Antimicrob Agents. 2006 May;27(5):367-75. doi: 10.1016/j.ijantimicag.2005.12.004. PMID: 16647842.

11. Jennifer LB. Bacterial Gastroenteritis. Medscape. 2020 Oct. emedicine.medscape.com/article/176400-overview.

12. Carmeli, Y., Samore, M., Shoshany, O. et al. Utility of clinical symptoms versus laboratory tests for evaluation of acute gastroenteritis. Digest Dis Sci 41, 1749-1753 (1996). https://doi.org/10.1007/BF02088740

\section{Figures}

956 patients who came to Emergency Department due to Gastroenteritis conditions

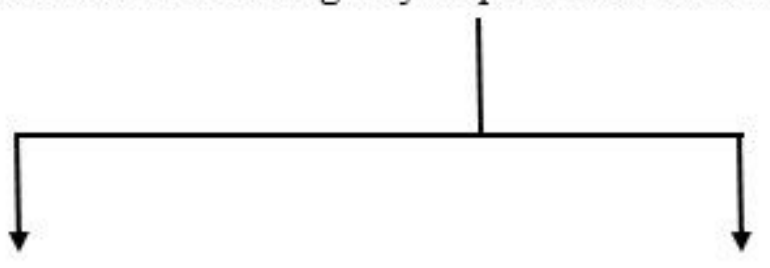

756 patients included in the study

200 patients were excluded in the study

112 did not proceed with follow-

up consultation or laboratory test not done were excluded

88 with were excluded as it falls

$\rightarrow$ part in the exclusion criteria list 
Figure 1

Flow chart of study participants.

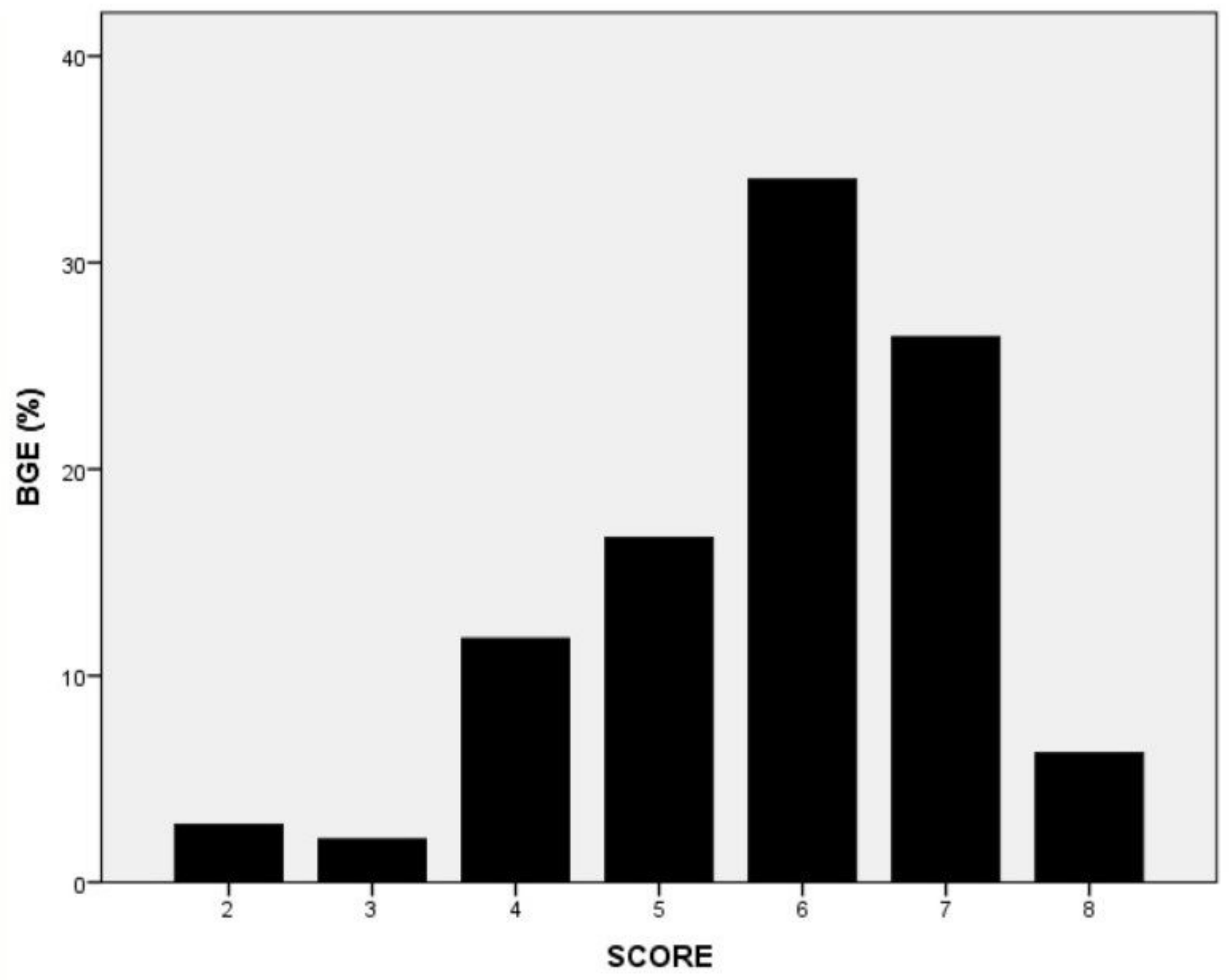

Figure 2

Rate of BGE versus score in 756 participants. 